University of Nebraska - Lincoln

DigitalCommons@University of Nebraska - Lincoln

Faculty Papers and Publications in Animal

Science

Animal Science Department

2006

\title{
Influence of Corn Hybrid Traits on Digestibility and the Efficiency of Gain in Feedlot Cattle
}

\author{
S. L. Jaeger \\ University of Nebraska-Lincoln \\ Matt K. Luebbe \\ University of Nebraska-Lincoln, mluebbe2@unl.edu \\ C. N. Macken \\ University of Nebraska-Lincoln \\ Galen E. Erickson \\ University of Nebraska-Lincoln, gerickson4@unl.edu \\ Terry J. Klopfenstein \\ University of Nebraska-Lincoln, tklopfenstein1@unl.edu \\ See next page for additional authors
}

Follow this and additional works at: https://digitalcommons.unl.edu/animalscifacpub

Part of the Animal Sciences Commons

Jaeger, S. L.; Luebbe, Matt K.; Macken, C. N.; Erickson, Galen E.; Klopfenstein, Terry J.; Fithian, W. A.; and Jackson, David S., "Influence of Corn Hybrid Traits on Digestibility and the Efficiency of Gain in Feedlot Cattle" (2006). Faculty Papers and Publications in Animal Science. 465.

https://digitalcommons.unl.edu/animalscifacpub/465

This Article is brought to you for free and open access by the Animal Science Department at DigitalCommons@University of Nebraska - Lincoln. It has been accepted for inclusion in Faculty Papers and Publications in Animal Science by an authorized administrator of DigitalCommons@University of Nebraska - Lincoln. 


\section{Authors}

S. L. Jaeger, Matt K. Luebbe, C. N. Macken, Galen E. Erickson, Terry J. Klopfenstein, W. A. Fithian, and David S. Jackson 


\title{
Influence of corn hybrid traits on digestibility and the efficiency of gain in feedlot cattle ${ }^{1}$
}

\author{
S. L. Jaeger, ${ }^{*}$ M. K. Luebbe, * C. N. Macken,* G. E. Erickson, ${ }^{* 2}$ T. J. Klopfenstein,* \\ W. A. Fithian, $\dagger$ and D. S. Jackson $\ddagger$ \\ *Department of Animal Science, University of Nebraska, Lincoln 68583; †Golden Harvest Seeds Inc., \\ Waterloo, NE; $\ddagger$ Department of Food Science and Technology, University of Nebraska, Lincoln 68583
}

\begin{abstract}
Two experiments were conducted to determine the influence of chemical and physical corn kernel traits on digestibility and feedlot cattle performance. Seven commercially available corn hybrids representing a range in kernel traits were evaluated for a variety of chemical and physical traits that included test weight, 1,000-grain weight, kernel size, starch, CP, amylose, Stenvert Hardness tests (kernel hardness traits), tangential abrasive dehulling device loss, 12-h in vitro starch disappearance, and rate and extent of in situ DM disappearance. Differences among hybrids existed for all physical kernel traits measured. In Exp. 1, 224 steers in 28 pens were fed the same hybrids for $167 \mathrm{~d}$ in a completely randomized design. All diets were formulated to have $12.5 \% \mathrm{CP}$ and contained $66 \%$ dryrolled corn (DM basis). There were no differences ( $P>$ 0.20 ) among corn hybrids for DMI, ADG, or carcass characteristics. However, efficiency of gain (G:F) was influenced by hybrid $(P<0.01)$ with a difference of 9.5\% from the least to the most efficient. In Exp. 2, 7
\end{abstract}

ruminally cannulated heifers were used in a $7 \times 7$ Latin square design to determine the effects of these hybrids on nutrient digestibility, VFA concentrations, and ruminal $\mathrm{pH}$. Total-tract $\mathrm{OM}$ and starch digestibilities were not different $(P>0.15)$ among hybrids and averaged 77.9 and $95.1 \%$, respectively. Differences $(P<0.05)$ among hybrids existed for ruminal propionate concentration and the acetate to propionate ratio. Kernel hardness traits correlated $(P<0.05)$ with $\mathrm{G}$ : F were $1,000-$ grain weight $(r=-0.81)$, Stenvert time to grind $(r=$ -0.83 ), and the proportion of Stenvert soft to coarse particle height $(r=0.83)$. Propionate concentration was not correlated $(\mathrm{r}=0.45)$ with $\mathrm{G}: \mathrm{F}$ but was correlated $(P=0.02)$ to the Stenvert time to grind $(\mathrm{r}=-0.83)$. Cattle fed dry-rolled corn hybrids with greater proportions of soft endosperm had greater concentrations of propionate and gained more efficiently than cattle fed hybrids with a harder endosperm. Selecting for these softer kernel traits may improve the efficiency of gain in feedlot cattle.

Key words: cattle, feed efficiency, feedlot, hybrids, maize, starch digestion

(C2006 American Society of Animal Science. All rights reserved.

J. Anim. Sci. 2006. 84:1790-1800 doi:10.2527/jas.2005-570

\section{INTRODUCTION}

Corn is the major component of most feedlot diets in the United States (Galyean, 1996) because of its energy content relative to cost and production characteristics. Much work has been done to examine the effects of corn processing on digestibility and feedlot animal performance (Owens et al., 1997; Cooper et al., 2002); however, data collected to determine the influence of chemical and physical properties of corn on performance are

\footnotetext{
${ }^{1}$ A contribution of the Univ. of Nebraska Agric. Res. Div., Lincoln, NE. Journal Series No. 14678. This research was supported in part by funds provided through the Hatch Act.

${ }^{2}$ Corresponding author: geericks@unlnotes.unl.edu

Received October 5, 2005.

Accepted February 9, 2006.
}

limited. If performance differences relating to physical properties, chemical properties, or both can be identified, they would be useful for discriminating among grain sources when purchasing corn grain. In vitro rate of cornstarch digestion (IVRSD) has been shown to be correlated with G:F ( $\mathrm{r}^{2}=0.58$; Ladely et al., 1995). Cattle fed hybrids with a faster IVRSD have been observed to gain faster and more efficiently than cattle fed hybrids with a slower IVRSD. These results may be due to an increase in ruminal starch digestion.

Corn characteristics commonly measured are in relation to mass or volume (i.e., yield and test weight). However, other kernel measurements exist that may be more pertinent for the purpose of feeding corn to livestock. Some of these kernel traits include vitreousness, ratio of amylose to amylopectin, 1,000-grain weight, and kernel hardness (Shandera et al., 1997). 
In-situ ruminal digestibility can be predicted by vitreousness $\left(r^{2}=0.89\right)$ of the kernel (Philippeau et al., 1999). Additionally, Philippeau et al. (1999) also reported that ruminal starch degradability can be predicted by combining apparent density with 1,000-grain weight $\left(R^{2}=\right.$ 0.91). However, these kernel hardness traits have not been related to animal performance.

Therefore, the objective of this research was to examine 7 different commercially available corn hybrids varying in chemical and physical properties and to determine the impact of these kernel traits on nutrient digestibility, VFA concentrations, and cattle performance on high-grain diets.

\section{MATERIALS AND METHODS}

The University of Nebraska's Institutional Animal Care and Use Committee approved all procedures and guidelines involving animals.

\section{Grain Production and Analysis}

Seven commercially available dent corn hybrids, representing a wide range in physical and chemical kernel traits, were planted and grown under center-pivot irrigation in 2 similar fields at the University of Nebraska Agricultural Research and Development Center (ARDC, Mead, NE) during the 2002 growing season. The 7 hybrids consisted of Golden Harvest (Golden Harvest Seeds Inc., Waterloo, NE) H-9164Bt (1), H-9235Bt/ RR (2), H-9230Bt (3), Pioneer (Pioneer Hi-Bred International Inc., Des Moines, IA) 33B51 (4), and 33P67 (5), and Golden Harvest H-8562 (6), and H-9533Bt (7). All of the hybrids were represented equally in each of the 2 fields.

The grain was harvested between 14 and $18 \%$ moisture within a 2-d period and stored until preparation for the feeding trial. Corn grain from both fields was combined for each hybrid and stored in separate grain bins. At harvest, each truckload was sampled in 2 replications within each field, resulting in 4 representative samples per hybrid. Samples were placed in nylon mesh bags in the same room for 2 mo to allow for moisture to equilibrate among hybrids. Samples were analyzed as replicate within field $(n=4)$ as the experimental unit for each hybrid based on samples taken at harvest.

Three hardness tests were conducted. The proportion of light density kernels was determined by immersing a sample of 50 kernels in a solution of sodium nitrate at $60^{\circ} \mathrm{C}$, which corresponded to a specific gravity of $1.275 \mathrm{~g} / \mathrm{cm}^{3}$ (Bergquist and Thompson, 1992). The proportion of light density kernels was calculated as the percentage of kernels that remained floating on top of the solution.

A tangential abrasive dehulling device (TADD, Model 4E-220, Venables Machine Works, Saskatoon, Canada) was used to determine the TADD loss when abraded in the device. A 40-g sample of corn was abraded in the TADD for 10 min while excess material was suctioned off. The TADD loss was calculated as the percent of kernel material suctioned off during the abrading process. These results were used as an indication of kernel hardness (Reichert et al., 1986).

Stenvert Hardness tests were conducted using 20-g samples of corn and grinding them using a microhammermill (Micro Hammer Mill V, Glen Mills Inc., Maywood, NJ) with a 2-mm screen at $360 \mathrm{rpm}$. Measurements taken included: time to grind, reduced hammermill speed at maximum grinding power, heights of soft endosperm and total ground material in the recovery column, and weight of hard endosperm recovered over a 425- $\mu \mathrm{m}$ sieve (Pomeranz et al., 1985).

Kernel test weight was determined using a Dickey John grain analysis computer (Model GAC II, Dickey John Corp., Auburn, IL). Thousand-grain weight was determined by weighing 1,000 kernels that had been counted using a Seedburo 801 count-a-pak seed counter (Seedburo Equipment Co., Chicago, IL). Kernels were categorized by shape and size using a miniature sizing tool (Golden Harvest) that mimics kernel sizing of seed corn by the seed industry during the conditioning process. The sizing tool operates on the same principle as a sieving method and separates kernels into an array of sizes within 2 broad shape categories: flat and round. This process uses a series of screens to separate flatshaped kernels from more round-shaped kernels, and additional screens to divide kernels into multiple size sublots within both shape categories. As the screens are shaken, gravity causes corn kernels to drop through the screens until they can no longer fit through the screen holes, at which time they are trapped in the pan walls attached to the top of that screen.

A 100-g sample of corn was initially placed on the top screen, which has hole sizes of $0.52 \mathrm{~cm}$ in width. This screen prevents passage of round kernels but allows flat-shaped kernels to pass through. Underneath the flat screen were 5 screens with round holes 0.91 , $0.83,0.75,0.68$, and $0.60 \mathrm{~cm}$ in diam., as well as a catchall pan to collect all broken kernel pieces or foreign material. These screens separated and captured the different sizes of sublots of flat kernels in the sample. The sample was sieved for 5 min to separate the round kernels (remaining on top of the flat screen) from the flat kernels, and the largest flat kernels from several sizes of smaller flat kernels. The flat kernels came to rest on their respective screens, and the weight of the kernels on each screen was recorded. Additionally, the weight of the round kernels caught by the top flat screen was recorded, and the flat screen was then removed for the round kernels to be sieved and segregated into their respective kernel sizes.

Laboratory DM of 1-mm of ground corn was determined by drying samples in a $100^{\circ} \mathrm{C}$ oven for $24 \mathrm{~h}$. Crude protein content $(\% \mathrm{~N} \times 6.25)$ of corn samples was determined using a combustion-method $\mathrm{N}$ analyzer (Leco FP-528, Leco Corp., St. Joseph, MI) according to the AOAC (1995) procedure. Total starch content was determined using an enzymatic procedure of Zinn 
(1990). The quantitative yield of glucose from starch was determined by determining the absorption at 630 nm using a Spectramax 250 spectrophotometer (Molecular Devices Corp., Sunnyvale, CA). Amylose content was measured by colorimetric determination at 620 and $510 \mathrm{~nm}$, as described by Zhu (2002); values were determined using a calibration curve that was prepared using corn amylose standards.

A 12-h in vitro starch degradation procedure was conducted to determine starch disappearance using the methods of Richards et al. (1995). Two sizes of grind were used, a 1-mm fine grind and a simulated masticate grind. The 1-mm fine grind was produced using a model 1093 Cyclotec sample mill (Foss Tecator, Eden Prairie, $\mathrm{MN})$. The simulated masticate grind was produced by passing whole-kernel corn samples through a ThomasWiley mill No. 4 with a $0.635-\mathrm{cm}$ screen for a total of $10 \mathrm{~s}$ to simulate masticated corn (Simon, 2001).

Dry-rolled corn from each hybrid was analyzed for particle size determination. United States Bureau of Standard (USBS) Sieves \#1 (9,500- $\mu \mathrm{m}$ screen opening), \#3 (6,300 $\mu \mathrm{m}), \# 4(4,760 \mu \mathrm{m}), \# 6(3,360 \mu \mathrm{m}), \# 12(1,680$ $\mu \mathrm{m}), \# 30(590 \mu \mathrm{m})$, and \#70 $(212 \mu \mathrm{m})$ were used for determination of the geometric mean diam. $(\mu \mathrm{m})$ and geometric SD for each hybrid. The USBS sieves were placed in a Fritsch Analysette wet sieving device (Model 8751, Fritsch-GmbH, Idar-Oberstein, Germany) for particle size analysis. The sieves were placed in the following order, from top to bottom, \#1, \#3, \#4, \#6, \#12, $\# 30$, and \#70.

Approximately $30 \mathrm{~g}$ of sample (DM) were evenly distributed across the top screen, and the cap was secured onto the device. Samples were subjected to a 5-min period of vibration and spray, which moved the particles down through the screens. Particles from each separate screen were cleaned onto preweighed filter papers that were dried for $24 \mathrm{~h}$ at $100^{\circ} \mathrm{C}$. Filter papers and sample retained on each screen were weighed after being dried for $24 \mathrm{~h}$ at $100^{\circ} \mathrm{C}$. Duplicate samples of each hybrid underwent this procedure. The geometric mean diam. and the geometric SD for the samples were calculated by the method described by Behnke (1994).

The final segment of the grain analysis involved an in situ study utilizing 2 ruminally cannulated crossbred yearling heifers (approximately $500 \mathrm{~kg}$ of BW). Ruminal cannulas were surgically placed in each heifer approximately 1 yr before this trial began, according to the procedures outlined by Stock et al. (1990). Heifers were housed in $1.5 \times 2.4 \mathrm{~m}$, individual, slotted-floor stalls within a temperature-controlled room $\left(25^{\circ} \mathrm{C}\right)$. The animals had been previously adapted to a mixed diet, which consisted of $70 \%$ grass hay, $14.8 \%$ dry-rolled corn, $14.8 \%$ soybean meal, and $0.4 \%$ supplement (DM basis), and were fed twice daily at 0800 and 1600 . Dacron bags $(5 \times 10 \mathrm{~cm}, 53-\mu \mathrm{m}$ pore size; Ankom, Fairport, NY) were filled with $10 \mathrm{~g}$ (DM) of simulated masticate corn sample and heat-sealed. One hundred forty bags [28 samples $\times 5$ time points $(0,8,16,24$, and $72 \mathrm{~h})]$ were replicated using 2 replicates across 2 heifers (1 bag/ replicate), for a total of 560 bags.

Two weighted mesh bags containing 14 Dacron bags for each time point were placed into the rumen of each heifer. The mesh bags containing the Dacron bags were placed in the rumen of the heifers at each respective time point, and all bags were removed after the final time point. The mesh bags were emptied, and the $\mathrm{Da}-$ cron bags were rinsed in a washing machine with $40 \mathrm{~L}$ of $39^{\circ} \mathrm{C}$ water using 5 rinsing cycles, each consisting of $1 \mathrm{~min}$ of agitation and $2 \mathrm{~min}$ of spin. Fresh water was added before each cycle after the draining of the water from the spin cycle. Once rinsing was completed, the Dacron bags were placed into a wire basket and dried in a $60^{\circ} \mathrm{C}$ forced-air oven for $24 \mathrm{~h}$. After drying, the bags containing residue were cooled, desiccated, and weighed to determine sample DM disappearance. The extent of digestion was calculated using the 72-h time point. In situ rate of DM disappearance was calculated assuming first-order kinetics (Mertens, 1987).

\section{Experiment 1}

Two hundred twenty-four crossbred steer calves (277 $\pm 7.4 \mathrm{~kg}$ of BW) were used in a completely randomized design to evaluate the effects of chemical and physical corn kernel traits on finishing performance and carcass composition. Steers were limit-fed for $5 \mathrm{~d}$ at $2 \% \mathrm{BW}$ (5.5 kg). Limit-fed weights were taken on 2 consecutive mornings before initiation of the trial to reduce the effects of differences in gut fill on steer weights. The steers were stratified by weight and assigned randomly within weight strata to 1 of 28 pens ( 8 steers/pen). Pens were assigned randomly to 1 of 7 corn hybrids.

Diets were formulated to meet or exceed the NRC (1996) requirements for protein (12.5\%), calcium $(0.7 \%)$, potassium $(0.65 \%)$, and phosphorus $(0.4 \%)$. Cattle were adapted to grain by feeding $35,25,15$, and $5 \%$ alfalfa hay (DM basis) replaced by corn in each treatment and fed for $3,4,7$, and $7 \mathrm{~d}$, respectively. The final diet composition (DM basis) consisted of $66.0 \%$ dry-rolled corn, $20.0 \%$ wet corn gluten feed (Sweet Bran, Cargill, Blair, NE), 10.0\% corn silage, and 4.0\% supplement. Whole corn was transported to the research feedlot at the Agricultural Research and Development Center (Mead, NE) as needed, where it was dry-rolled and placed in separate commodity bays until fed. The rollers on the mill were placed at the same setting for all hybrids. The supplement was identical for all diets and was formulated to meet protein requirements based on the corn hybrid with the lowest CP value. All diets contained monensin $(29 \mathrm{mg} / \mathrm{kg}$ of DM; Elanco Animal Health, Indianapolis, IN) and tylosin (10 mg/kg of DM; Elanco Animal Health).

Cattle were fed once daily at 0800 and allowed ad libitum access to feed and water. Each steer was implanted with Synovex-S (Fort Dodge Animal Health, Overland Park, KS) at trial initiation and reimplanted on d 71 with Revalor-S (Hoechst Roussel, Somerville, 
NJ). Body weights were also taken at the time of reimplanting. Cattle were on trial for $167 \mathrm{~d}$ and killed at a commercial abattoir (Tyson, West Point, NE), where carcass data were collected. Hot carcass weight and liver abscess scores were taken on the day of slaughter. Livers were scored for abscesses using the procedures of Brink et al. (1990). After a 24-h chill, 12th-rib fat thickness, USDA called marbling score, and LM area were recorded. Longissimus muscle area was measured using chromatography paper scanned with Meatscan Image Analyzer software (AEW Consulting, Lincoln, $\mathrm{NE}$ ).

Hot carcass weight adjusted for $63 \%$ dressing percent was used to calculate final body weight. These calculated final weights were used to minimize differences in gut fill. Average daily gain and G:F were calculated using the final body weight based on the carcass weight.

\section{Experiment 2}

Seven ruminally cannulated yearling heifers (512 \pm $11 \mathrm{~kg}$ of BW) were used in a $7 \times 7$ Latin square design with 14-d periods consisting of a 9-d adaptation followed by a 5 -d collection period. Diets (DM basis) consisted of $68.5 \%$ dry-rolled corn hybrid, $20.0 \%$ wet corn gluten feed (Sweet Bran), 7.5\% alfalfa, and 4.0\% supplement. The supplement in Exp. 2 was the same as that fed in Exp. 1. Diets were fed once daily at 0700 for ad libitum intake. Feed refusals were collected on d 9 to 14 , weighed, and subsampled. Heifers were individually fed in pens during the adaptation on $d 1$ to 9 and moved into stanchions for the collection period on $d$ 10. Feed intake and ruminal $\mathrm{pH}$ were continuously monitored on d 10 through 14 using feed bunks suspended from load cells and submersible $\mathrm{pH}$ electrodes, respectively (Cooper et al., 1999). Laboratory DM, CP, and total starch content of feed ingredients, feed refusals, and fecal samples were determined using the same procedures as those used for corn grain analysis.

Fecal output was estimated by giving the heifers a 7.5-g bolus of chromic oxide twice daily ( 0700 and 1900) via rumen cannula on $\mathrm{d} 7$ through 14 . On d 10 through 14, fecal grab samples were collected 3 times daily and immediately frozen. Fecal samples and feed refusals for each heifer in each period were composited, freezedried, and ground in a Wiley mill (Thomas Scientific, Swedesboro, NJ) to pass through a 1-mm screen. Chromium concentration of feces was determined by atomic absorption spectrophotometry using an air-acetylene flame according to Williams et al. (1962). Fecal output (g/d) was calculated as chromium bolused ( $\mathrm{g} / \mathrm{d}$ ) divided by the fecal chromium concentration $(\mathrm{g} / \mathrm{g})$.

Ruminal fluid samples were collected during ruminal $\mathrm{pH}$ data collection using the suction strainer technique (Raun and Burroughs, 1962), via the rumen cannula, and immediately frozen. Ruminal fluid samples were taken on d 14 before feeding and every $2 \mathrm{~h}$ for $12 \mathrm{~h}$. At the completion of the experiment, ruminal fluid samples were thawed to measure VFA concentration using the procedures of Erwin et al. (1961). Ruminal fluid samples were analyzed in a Hewlett Packard gas chromatograph (Series II, 5890) using a Supelco 12144 column.

\section{Statistics}

Data from kernel trait analysis were analyzed using the MIXED procedure of SAS (SAS Inst. Inc., Cary, NC). The model effects for all laboratory data, except in situ and particle size data, were hybrid, field, and the interaction of hybrid and field. The model effects for the in situ data were hybrid, field, steer, day, and all of the respective interactions. The model effect for particle size was hybrid. Least squares means were separated using the least significant difference method when a significant $F$-test $(P<0.05)$ was detected. Experiment 1 data were analyzed as a completely randomized design using the MIXED procedure of SAS. Least squares means were separated using the least significant difference method when a significant $F$-test $(P<$ $0.05)$ was detected. Animal performance and carcass data analysis utilized pen as the experimental unit and the model effect was hybrid. The CORR procedure of SAS was used to test for correlations among G:F, kernel traits, and digestibility data.

Nutrient digestibility data (Exp. 2) were analyzed as a $7 \times 7$ Latin square design using the MIXED procedure of SAS. Animal within period was the experimental unit. The model consisted of animal, period, and dietary treatment. Animal within period was a random effect. Least squares means were separated using the Least Significant Difference method when a significant $F$-test $(P<0.05)$ was detected.

Ruminal $\mathrm{pH}$, intake, and VFA data were analyzed as repeated measures using the MIXED procedure of SAS. Animal within period was the experimental unit. The model consisted of animal, period, time, and dietary treatment. Time of the 7 observations within a day was the repeated variable for VFA data. Day within collection period was a repeated variable for intake patterns and ruminal $\mathrm{pH}$. The autoregressive structure was used as the covariance structure for VFA, intake patterns, and ruminal $\mathrm{pH}$ data (Littell et al., 1998). Least squares means were separated using the least significant difference method when a significant $F$-test $(P<0.05)$ was detected.

\section{RESULTS}

\section{Corn Grain Production and Analyses}

The average yield for each of the test hybrids 1 through 7 was $14.4,13.0,13.9,13.1,13.9,12.7$, and 13.0 ( $15.5 \%$ corrected moisture) t/ha, respectively. Whereas numerical differences existed, the experiment was not designed statistically to test yield. Percent CP (DM basis) ranged from 9.0 to $10.1 \%$ among hybrids (Table 1 ). Percent CP was greater $(P<0.01)$ for hybrids 2,5 , and 
Table 1. Differences in kernel characteristics among corn hybrids

\begin{tabular}{|c|c|c|c|c|c|c|c|c|c|}
\hline Item & \multicolumn{7}{|c|}{ Hybrid $^{1}$} & SEM & $P$ value $^{2}$ \\
\hline Starch, \% & 75.4 & 75.6 & 71.8 & 73.8 & 74.4 & 73.4 & 73.8 & 1.2 & \\
\hline 1,000 -grain wt, $\mathrm{g}$ & $318.2^{\mathrm{c}}$ & $316.9^{\mathrm{c}}$ & $314.6^{\mathrm{cd}}$ & $310.9^{\mathrm{d}}$ & $326.2^{\mathrm{b}}$ & $344.3^{\mathrm{a}}$ & $340.9^{\mathrm{a}}$ & 1.3 & $<0.01$ \\
\hline Test wt, kg/L & $0.775^{\mathrm{e}}$ & $0.802^{\mathrm{b}}$ & $0.802^{\mathrm{b}}$ & $0.800^{\mathrm{b}}$ & $0.822^{\mathrm{a}}$ & $0.782^{\mathrm{d}}$ & $0.791^{\mathrm{c}}$ & 0.002 & $<0.01$ \\
\hline Fine IVSD, ${ }^{3} \%$ & 72.3 & 72.2 & 73.3 & 72.7 & 70.7 & 72.8 & 74.6 & 0.9 & 0.15 \\
\hline Light density, ${ }^{5} \%$ & $96.7^{\mathrm{a}}$ & $82.5^{\mathrm{b}}$ & $70.7^{\mathrm{c}}$ & $70.5^{c}$ & $12.7^{\mathrm{f}}$ & $49.0^{\mathrm{d}}$ & $35.3^{\mathrm{e}}$ & 2.2 & $<0.01$ \\
\hline TADD,${ }^{6} \%$ removed & $80.3^{\mathrm{a}}$ & $71.9^{\text {cd }}$ & $74.5^{\mathrm{bc}}$ & $82.7^{\mathrm{a}}$ & $70.5^{\mathrm{d}}$ & $75.8^{\mathrm{b}}$ & $73.2^{\mathrm{bcd}}$ & 1.0 & $<0.01$ \\
\hline Stenvert, ${ }^{7} \%$ hard & $26.9^{\mathrm{a}}$ & $27.6^{\mathrm{a}}$ & $28.5^{\mathrm{a}}$ & $22.6^{\text {cd }}$ & $26.1^{\mathrm{ab}}$ & $20.9^{\mathrm{d}}$ & $23.9^{b c}$ & 1.0 & $<0.01$ \\
\hline Stenvert, ${ }^{8} \mathrm{rpm}$ & $294.5^{\mathrm{ab}}$ & $292.1^{\mathrm{d}}$ & $293.3^{\mathrm{abc}}$ & $294.5^{\mathrm{a}}$ & $292.6^{\text {cd }}$ & $293.3^{\mathrm{bcd}}$ & $293.3^{\text {bcd }}$ & 0.4 & $<0.01$ \\
\hline Stenvert time ${ }^{9} \mathrm{~s}$ & $7.59^{\mathrm{de}}$ & $7.82^{\mathrm{cd}}$ & $9.68^{\mathrm{a}}$ & $8.07^{\mathrm{c}}$ & $8.68^{b}$ & $7.31^{\mathrm{e}}$ & $7.90^{\mathrm{cd}}$ & 0.17 & $<0.01$ \\
\hline Stenvert, ${ }^{10} \%$ soft & $71.6^{\mathrm{a}}$ & $67.4^{\mathrm{b}}$ & $64.0^{\mathrm{c}}$ & $67.9^{\mathrm{b}}$ & $63.0^{\mathrm{c}}$ & $72.6^{\mathrm{a}}$ & $71.0^{\mathrm{a}}$ & 1.1 & $<0.01$ \\
\hline \multicolumn{10}{|c|}{$\begin{array}{l}{ }^{3} \mathrm{IVSD}=12 \mathrm{~h} \text { in-vitro starch disappearance. Masticate samples were ground through a } 0.635 \text {-cm screen. Fine samples were ground through } \\
\text { a } 1 \text {-mm screen. }\end{array}$} \\
\hline \multicolumn{10}{|c|}{${ }^{4}$ Rate of DM disappearance. } \\
\hline \multirow{3}{*}{\multicolumn{10}{|c|}{$\begin{array}{l}{ }^{5} \text { Measured as } \% \text { of kernels floating in a solution of sodium nitrate solution, which responds to a specific gravity of } 1.275 . \\
{ }^{6} \text { Measured as percentage of original sample weight removed after abrasion by the Tangential Abrasive Dehulling Device (TADD). } \\
{ }^{7} \text { Measured as weight recovered over a } 425-\mu \text { m sieve divided by total sample weight. }\end{array}$}} \\
\hline & & & & & & & & & \\
\hline & & & & & & & & & \\
\hline \multirow{2}{*}{\multicolumn{10}{|c|}{${ }^{8}$ Reduction in hammermill speed from $360 \mathrm{rpm}$. }} \\
\hline \multirow{2}{*}{\multicolumn{10}{|c|}{${ }^{9}$ Measured time to grind $17 \mathrm{~mL}$ of sample. }} \\
\hline & & & & & & & & & \\
\hline \multicolumn{10}{|c|}{$\begin{array}{l}{ }^{10} \text { Measured as height in } \mathrm{cm} \text { and calculated as a percentage of total height. } \\
{ }^{11} \text { Geometric mean diameter calculated from Behnke. } 1994 .\end{array}$} \\
\hline
\end{tabular}

6 , compared with hybrids $1,3,4$, and 7 . A hybrid $\times$ field interaction $(P=0.04)$ was observed for percent amylose. Percent amylose was found to be 25.6, 23.1, 24.6, 30.5, $29.9,29.1$, and $26.0 \%$ for hybrids 1 through 7 , respectively, in field 1 . In field 2, percent amylose was 27.2 , 25.7, 24.0, 25.3, 28.6, 25.2, and $22.7 \%$ for hybrids 1 through 7 , respectively. There is not an apparent biological explanation for this hybrid $\times$ field interaction. Percent starch was $75.4,75.6,71.8,73.8,74.4,73.4$, and $73.8 \%$ for hybrids 1 through 7 , respectively. Based on original field replicate samples, starch values seemed too high. Percent starch presented here was not statistically analyzed because samples collected during the feeding trial were analyzed which did not account for field or replicate. Other analyses were conducted to determine if these starch values were logical, which included ash, NDF, ether extract, and CP. Twelve-hour in vitro starch disappearance was not different among hybrids and averaged $72.7 \pm 0.9 \%$ disappearance for the fine grind and $56.9 \pm 2.5 \%$ for the masticate grind. The 1,000-grain weight was greater $(P<0.01)$ for hybrids 6 and 7 compared with hybrids 1 through 5 . Differences were observed $(P<0.01)$ for test weight among hybrids. Test weight was lightest for hybrid $1(0.77 \mathrm{~kg} /$ L) and heaviest for hybrid $5(0.82 \mathrm{~kg} / \mathrm{L})$.

The proportion of light density kernels ranged from $12.7 \%$ (hybrid 5) to $96.7 \%$ (hybrid 1), indicating that hybrid 5 was the hardest $(P<0.01)$ and hybrid 1 the softest. However, the results from the TADD and Stenvert tests did not completely agree with the proportion of light density kernel test. The TADD test results indicated that hybrids 1 and 4 were the softest $(P<0.01)$ with 80.3 and $82.7 \%$, respectively, of the sample weight removed by the device. Hybrids 2, 5, and 7 were the hardest $(P<0.05)$ according to the TADD $(71.9,70.5$, and $73.2 \%$ removed, respectively). The 4 different Stenvert hardness test measurements conformed better with each other than the other hardness test measurements. In 3 out of 4 of the Stenvert measurements, hybrid 6 was the softest. The Stenvert hardness test that did not indicate hybrid 6 was the softest was the reduction of hammermill speed; however, hybrid 6 ranked second for this trait. Hardness tests indicated that hybrid 3 was the hardest as determined by the Stenvert percent hard weight, and the time to grind. The proportion of Stenvert soft particle height indicated hybrid 5 was the hardest (63.0\%); however, hybrid 3 was ranked second with only $64.0 \%$ soft particle height.

There were differences among hybrids for kernel size measurements (Table 2). Although there was no apparent relationship between kernel size (1,000-grain weight) or shape and hardness (Stenvert hardness tests and TADD test), there was a relationship in the proportion of round to flat kernels and hardness. Interestingly, hybrid 6 had the greatest $(P<0.01)$ proportion of round to flat kernel weight and also was the softest hybrid 
Table 2. Differences in kernel size among corn hybrids

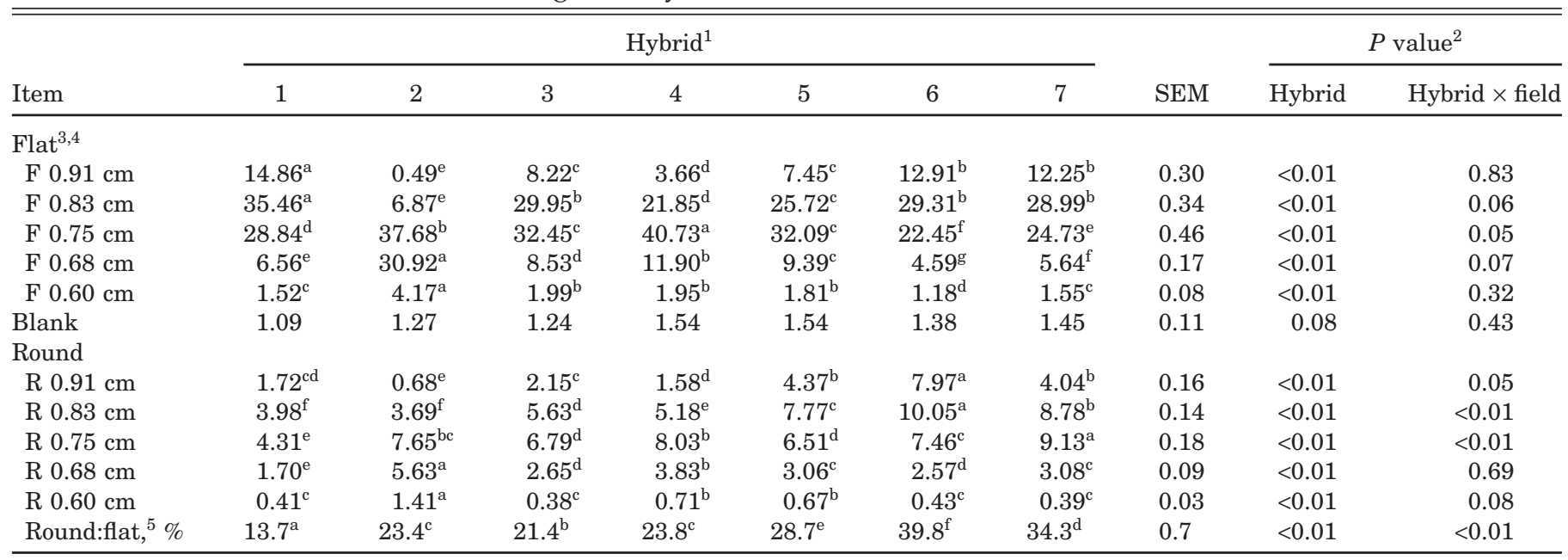

${ }^{\mathrm{a}-\mathrm{g}}$ Within a row, means without a common superscript letter $\operatorname{differ}(P<0.05)$.

${ }^{1}$ Hybrids consisted of Golden Harvest H-9164Bt (1), H-9235Bt/RR (2), H-9230Bt (3), Pioneer 33B51 (4), and 33P67 (5), and Golden Harvest H-8562 (6), and H-9533Bt (7).

${ }^{2} F$-test statistic for the effect of hybrid and field $\times$ hybrid interaction.

${ }^{3}$ Proportion of sample weight per screen size for each hybrid.

${ }^{4}$ Screen sizes are $0.91,0.83,0.75,0.68$, and $0.60 \mathrm{~cm}$ in diameter.

${ }^{5}$ Proportion of round to flat kernels.

according to the Stenvert tests. The geometric mean diam. (GMD) for dry-rolled corn samples was 33\% greater $(P=0.01)$ for the average of hybrids $1,2,4,5$, 6 , and 7, compared with hybrid 3 (Table 1). Similarly, the geometric SD $($ GSD $)$ was greatest $(P<0.01)$ for hybrid 3 .

There were differences $(P=0.02)$ among hybrids for the in-situ disappearance variables (Table 3 ). The hybrid that had the slowest DM disappearance rate was hybrid $3(3.16 \% / \mathrm{h})$, whereas the hybrid with the fastest rate was hybrid $4(4.15 \% / \mathrm{h})$. Additionally, differences for DM disappearance among hybrids at each of the individual time points were observed. No single hybrid separates itself from the rest of the hybrids at all of the 5 different time points. However, 3 hybrids (1, 4, and 6) generally had a greater DM disappearance at 0 to $24 \mathrm{~h}$, whereas hybrids 3 and 5 were generally lower during these incubation times.

\section{Experiment 1}

Average DMI and ADG were $9.9 \mathrm{~kg}$ and $1.7 \mathrm{~kg}$, respectively, and were similar $(P>0.20)$ among hybrids. However, there were differences in feed efficiency $(P<0.01)$ among hybrids (Table 4). Cattle fed hybrid 6 had the greatest feed efficiency (G:F $=0.185)$, whereas hybrid 3 had the lowest ( $\mathrm{G}: \mathrm{F}=0.169$ ) among the 7 hybrids. The improvement in feed efficiency of hybrid 6 over hybrid 3 was $9.5 \%$. Hybrid 6 was also $5.7 \%$ more efficient than hybrids 2,4 , and 5 . Carcass characteristics did not differ $(P>0.10)$ among hybrids.

\section{Experiment 2}

Dry matter, OM, and starch intakes were similar $(P=$ 0.90 ) among hybrids and averaged 9.8, 9.1, and $5.3 \mathrm{~kg}$, respectively (Table 5). Total tract DM, OM, and starch

Table 3. Differences in in-situ percent DM disappearance at various time points among corn hybrids

\begin{tabular}{|c|c|c|c|c|c|c|c|c|c|}
\hline \multirow[b]{2}{*}{ Item } & \multicolumn{7}{|c|}{ Hybrid $^{1}$} & \multirow[b]{2}{*}{ SEM } & \multirow[b]{2}{*}{$P$ value ${ }^{2}$} \\
\hline & 1 & 2 & 3 & 4 & 5 & 6 & 7 & & \\
\hline $\begin{array}{l}\text { Rate, } \% / \mathrm{h} \\
\text { Time, } \mathrm{h}\end{array}$ & $3.63^{\mathrm{ab}}$ & $3.74^{\mathrm{b}}$ & $3.16^{\mathrm{a}}$ & $4.15^{\mathrm{c}}$ & $3.17^{\mathrm{a}}$ & $3.63^{\mathrm{ab}}$ & $3.24^{\mathrm{ab}}$ & 0.21 & 0.02 \\
\hline 0 & $9.95^{\mathrm{a}}$ & $7.90^{\mathrm{bc}}$ & $5.81^{\mathrm{d}}$ & $9.16^{\mathrm{ab}}$ & $6.55^{\mathrm{cd}}$ & $9.76^{\mathrm{a}}$ & $6.85^{\mathrm{bc}}$ & 0.50 & $<0.01$ \\
\hline 8 & $38.2^{\mathrm{a}}$ & $34.2^{\mathrm{ab}}$ & $31.8^{\mathrm{b}}$ & $36.0^{\mathrm{ab}}$ & $33.5^{\mathrm{b}}$ & $36.0^{\mathrm{ab}}$ & $32.0^{\mathrm{b}}$ & 1.6 & 0.06 \\
\hline 16 & $50.3^{\mathrm{ab}}$ & $47.4^{\mathrm{bc}}$ & $45.8^{c}$ & $50.4^{\mathrm{ab}}$ & $47.1^{\mathrm{bc}}$ & $53.1^{\mathrm{a}}$ & $47.5^{\mathrm{bc}}$ & 1.4 & $<0.01$ \\
\hline 24 & $63.7^{\mathrm{a}}$ & $60.4^{\mathrm{abc}}$ & $56.9^{\mathrm{bc}}$ & $59.0^{\mathrm{abc}}$ & $55.3^{c}$ & $61.9^{\mathrm{ab}}$ & $61.9^{\mathrm{ab}}$ & 2.0 & 0.06 \\
\hline 72 & $91.9^{\mathrm{abc}}$ & $94.8^{\mathrm{a}}$ & $90.0^{\mathrm{bc}}$ & $94.9^{\mathrm{a}}$ & $89.6^{\mathrm{bc}}$ & $93.1^{\mathrm{ab}}$ & $89.1^{\mathrm{b}}$ & 1.4 & 0.01 \\
\hline
\end{tabular}

${ }^{\mathrm{a}-\mathrm{d}}$ Within a row, means without a common superscript letter differ $(P<0.05)$.

${ }^{1}$ Hybrids consisted of Golden Harvest H-9164Bt (1), H-9235Bt/RR (2), H-9230Bt (3), Pioneer 33B51 (4), and 33P67 (5), and Golden Harvest H-8562 (6), and H-9533Bt (7).

${ }^{2} F$-test statistic for the effect of hybrid. 
Table 4. Effects of corn hybrid on steer performance and carcass characteristics

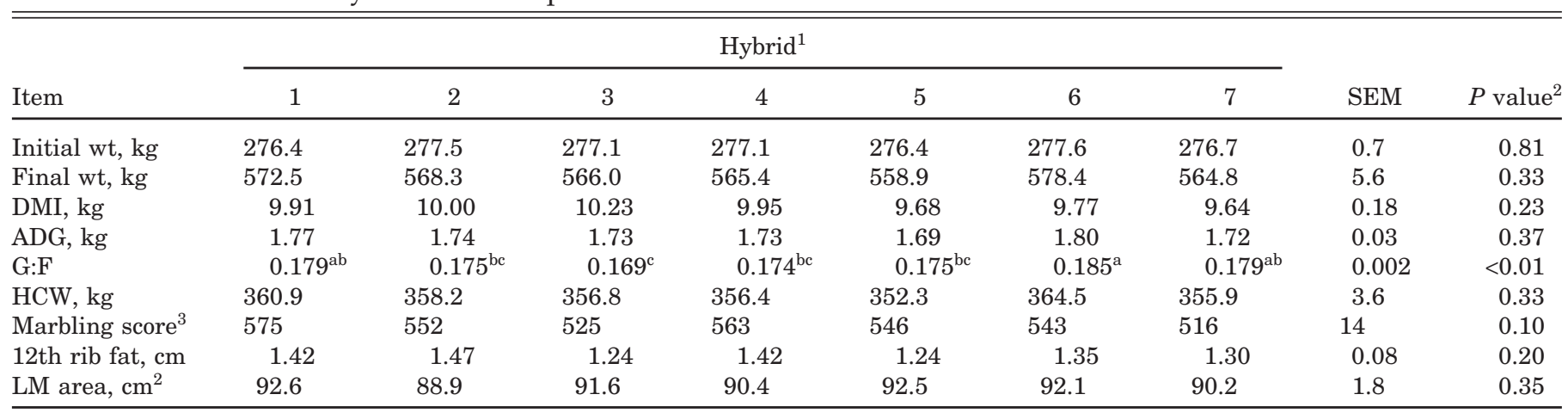

${ }^{\mathrm{a}-\mathrm{c}}$ Within a row, means without a common superscript letter differ $(P<0.05)$.

${ }^{1}$ Hybrids consisted of Golden Harvest H-9164Bt (1), H-9235Bt/RR (2), H-9230Bt (3), Pioneer 33B51 (4), and 33P67 (5), and Golden Harvest H-8562 (6), and H-9533Bt (7).

${ }^{2} F$-test statistic for the effect of hybrid.

${ }^{3} 450=$ Slight $^{50}, 500=$ Small $^{0}, 550=$ Small $^{50}$, etc.

digestibilities were similar $(P>0.19)$ among treatments (Table 5).

Dry matter, OM, and starch digestibilities averaged $77.0,77.9$, and $95.1 \%$, respectively. There were no differences $(P>0.10)$ in number of meals, total time spent eating, and intake rate among treatments (data not shown). Heifers consumed an average of $7.2 \pm 0.7$ meals per $\mathrm{d}$ at a rate of $16.6 \pm 2.4 \% / \mathrm{h}$. Total time spent eating averaged $600 \pm 37 \mathrm{~min} / \mathrm{d}$.

Cattle consuming hybrid 3 had the lowest $(P<0.01)$ propionate concentration among hybrids and the greatest $(P<0.01)$ acetate:propionate $(\mathbf{A : P})$ ratio (Table 6$)$. Total VFA concentration was lower $(P<0.01)$ for hybrid 3 compared with hybrids $1,4,5,6$, and 7 . There were no significant time $\times$ hybrid interactions $(P>0.10)$ for any rumen fermentation characteristics measured. Both acetate and propionate concentrations were lowest before feeding (0630) and increased throughout the sampling day with peak concentration 5 to $7 \mathrm{~h}$ postfeeding (data not shown). The increase for acetate and propionate concentrations contributed to a peak in total VFA concentration 5 to $7 \mathrm{~h}$ postfeeding. During this time, the propionate molar proportion increased from 38 to
$40 \%$, whereas the molar proportion of acetate decreased from 45 to $43 \%$. The changes in acetate and propionate concentrations across time reduced the A:P ratio from a high of 1.35 before feeding to a low of 1.17 at $12 \mathrm{~h}$ after feeding (data not shown). Average $\mathrm{pH}$, maximum $\mathrm{pH}$, minimum $\mathrm{pH}$, and $\mathrm{pH}$ variance (variance of daily ruminal $\mathrm{pH}$ ) are shown in Table 6 . Ruminal $\mathrm{pH}$ measurements were not influenced $(P>0.18)$ by hybrid.

\section{DISCUSSION}

Several trials have examined animal performance as a result of feeding different corn hybrids. Gramlich et al. (1989) compared the finishing performance of cattle fed 3 different hybrids. These hybrids were fed at highmoisture levels ( $>21 \%$ moisture) in Exp. 1, and as dryrolled corn in Exp. 2. Differences in feed intake and feed efficiency were observed among hybrids at greater moisture levels (Exp. 1). However, differences in cattle performance were not detected when these same hybrids were fed as dry-rolled corn.

Another trial examining 3 different corn hybrids fed as dry-rolled or early harvested, high-moisture corn

Table 5. Effects of corn hybrid on nutrient intake and digestibility

\begin{tabular}{|c|c|c|c|c|c|c|c|c|c|}
\hline \multirow[b]{2}{*}{ Item } & \multicolumn{7}{|c|}{ Hybrid $^{1}$} & \multirow[b]{2}{*}{ SEM } & \multirow[b]{2}{*}{$P$ value } \\
\hline & 1 & 2 & 3 & 4 & 5 & 6 & 7 & & \\
\hline \multicolumn{10}{|l|}{ Dry matter } \\
\hline Intake, kg & 9.5 & 9.7 & 10.2 & 9.4 & 9.8 & 9.8 & 10.1 & 0.6 & 0.91 \\
\hline Digestibility, \% & 78.4 & 76.1 & 74.6 & 79.3 & 78.0 & 77.8 & 75.1 & 2.1 & 0.19 \\
\hline \multicolumn{10}{|l|}{ Organic matter } \\
\hline Intake, kg & 8.9 & 9.1 & 9.5 & 8.8 & 9.1 & 9.2 & 9.4 & 0.6 & 0.93 \\
\hline Digestibility, \% & 79.3 & 77.7 & 76.1 & 80.1 & 79.0 & 78.3 & 74.9 & 2.9 & 0.46 \\
\hline \multicolumn{10}{|l|}{ Starch } \\
\hline Intake, kg & 5.3 & 5.4 & 5.3 & 5.1 & 5.3 & 5.3 & 5.4 & 0.3 & 0.97 \\
\hline Digestibility, \% & 95.4 & 94.8 & 94.7 & 95.6 & 95.3 & 94.9 & 94.9 & 0.6 & 0.59 \\
\hline
\end{tabular}

${ }^{1}$ Hybrids consisted of Golden Harvest H-9164Bt (1), H-9235Bt/RR (2), H-9230Bt (3), Pioneer 33B51 (4), and 33P67 (5), and Golden Harvest H-8562 (6), and H-9533Bt (7).

${ }^{2} F$-test statistic for the effect of hybrid. 
Table 6. Effects of corn hybrid on VFA concentration and ruminal $\mathrm{pH}$

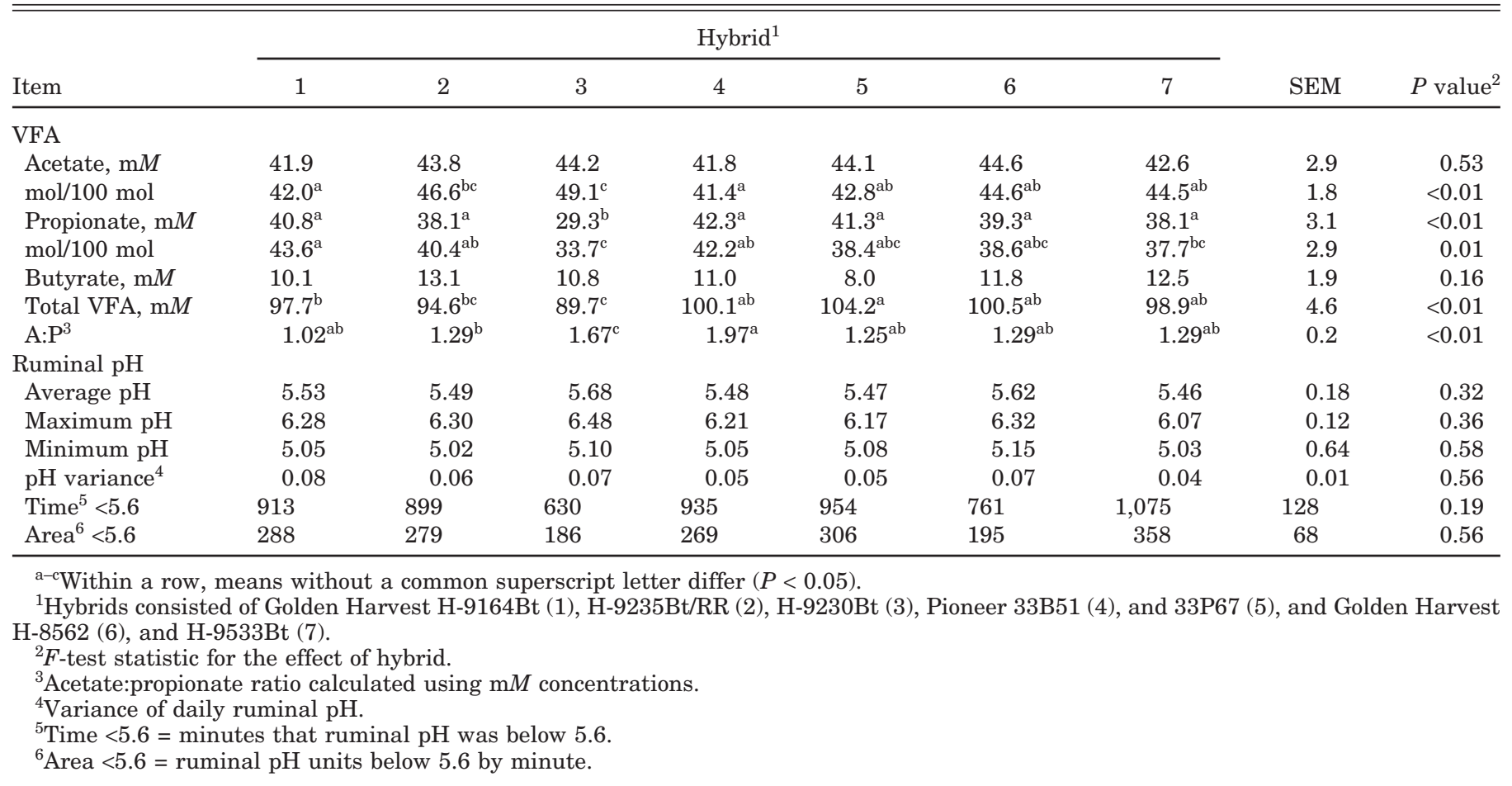

demonstrated an improved $\mathrm{G}: \mathrm{F}$ and $\mathrm{ADG}$ due to hybrid in yr 1 of the trial (Ladely et al., 1995). Additionally, in vitro rate of starch digestion differed among hybrids. Ladely et al. (1995) repeated the trial using the same hybrids and agronomic conditions and found no differences in performance due to hybrid in the second year; however, there were improvements in animal performance when corn was fed as high-moisture compared with dry-rolled. However, there were smaller differences for in vitro rate of starch digestion among hybrids in yr 2 than in yr 1, which may have minimized differences among hybrids for yr 2. This research implies there may be some inherent physical characteristics within the corn kernels resulting in differences in rate of starch digestion and ultimately animal performance.

Previous research examining physical characteristics of corn grain has found varying results. Philippeau et al. (1999) examined corn physical traits and the relationship with in situ ruminal starch degradation. Their study evaluated 14 different corn hybrids, 8 dent and 6 flint types. Characteristics measured included vitreousness, grinding energy, apparent and true densities, specific surface area, and 1,000-grain weight. Additionally, the grains were evaluated with an in situ trial examining their rate of DM and starch disappearance. Results from the study found that ruminal starch degradability could be predicted by vitreousness $\left(\mathrm{r}^{2}=0.89\right)$ or by combining apparent density and 1,000-grain weight $\left(R^{2}=0.91\right)$. The study demonstrated grain characteristics could be used to predict ruminal starch degradation; however, it did not examine these traits in an animal performance trial.

Results from our studies agree with some of the work performed by Philippeau et al. (1999). Whereas Phil- ippeau and others found that the 1,000-grain weight measurement could be useful in predicting ruminal degradability, our study indicates the 1,000-grain weight is a trait that is highly correlated with feed efficiency $(\mathrm{r}=0.81$; Table 7). As 1,000-grain weight increased, G:F increased. However, the increased 1,000-grain weight does not seem to be related to increased density because hybrid 6 was observed to have one of the lower test weights $(0.78 \mathrm{~kg} / \mathrm{L})$. The data indicate that kernels from hybrid 6 are larger and softer resulting in a greater 1,000 -grain weight without increased test weight. Interestingly, there was no relationship between feed efficiency and starch disappearance rate, which conflicts with previous research by Ladely et al. (1995).

A positive relationship was observed between the ratio of Stenvert soft to coarse particle height and G:F $(\mathrm{r}=0.83$; Table 7$)$. This was examined after finding the positive correlations for Stenvert soft height $(r=0.85)$ and total height ( $\mathrm{r}=0.78$ ) with $\mathrm{G}: \mathrm{F}$. As the proportion of soft particles increased, G:F increased. The Stenvert time to grind and G:F were also correlated; as time to grind the corn decreased, G:F increased ( $\mathrm{r}=-0.83)$. The Stenvert time to grind was related to kernel hardness, with a longer grinding time being indicative of harder kernels. Additionally, the ratio of coarse to soft particles (Stenvert \% hard) is an indicator of hardness, with the greater proportion of coarse particles representing a harder kernel.

Interestingly, VFA concentrations were not found to be correlated with G:F, but were significantly correlated to other measurements performed on the hybrids. The Stenvert time to grind was significantly correlated $(\mathrm{r}=$ $-0.84)$ with propionate concentrations. As the time to grind harder kernels increased, propionate concentra- 
Jaeger et al.

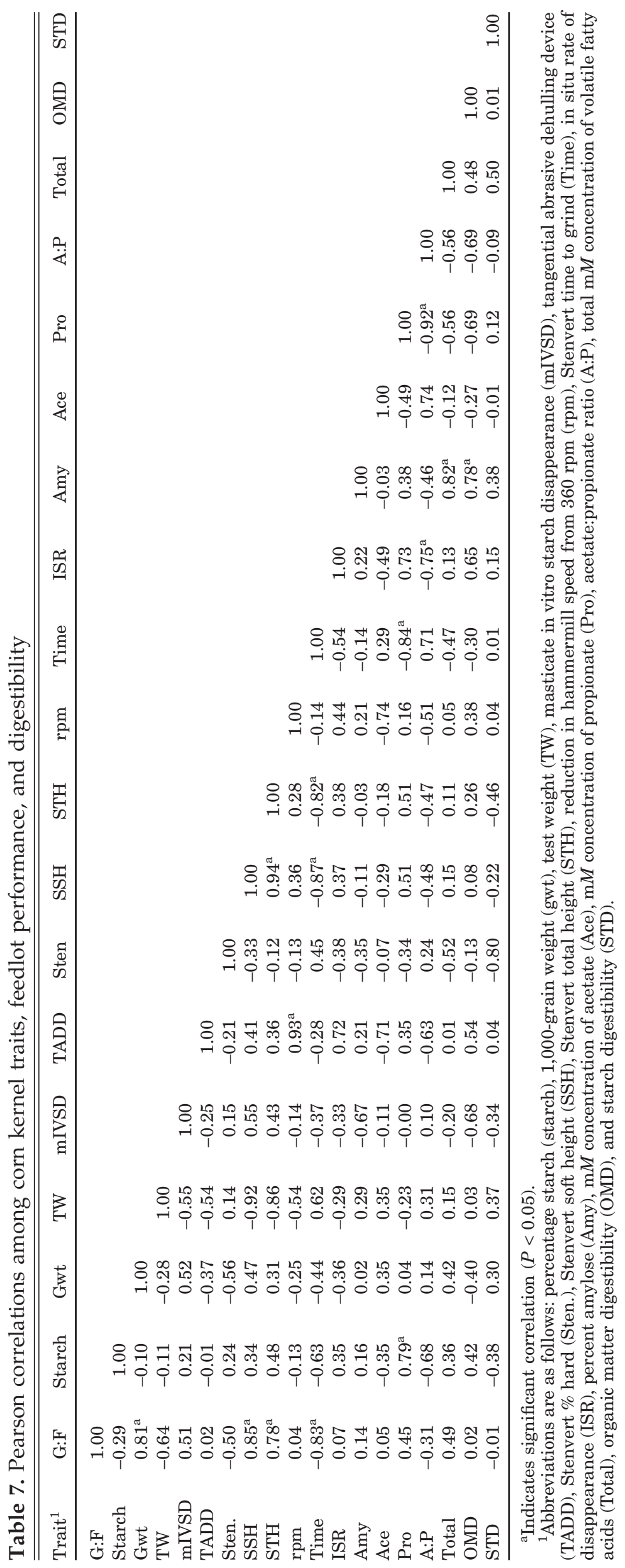


tion decreased. Additionally, the A:P ratio was correlated $(\mathrm{r}=-0.75)$ with the rate of in situ DM digestibility. As the A:P ratio decreased, the rate of in situ DM digestibility increased. These results indicate that starch in hybrids with harder kernel traits is not digested as rapidly or to the same extent in the rumen as in hybrids with softer kernels. A relationship also existed $(r=0.79)$ between percent starch and propionate concentration. As the percentage starch in the corn grain increased, propionate concentrations increased. However, because there were similar starch intakes among hybrids, the increase in propionate concentration was not due solely to a greater percentage starch in the grain.

Total VFA concentrations and OM digestibility were positively correlated $(P=0.03, \mathrm{r}=0.82$, and $P=0.04$, $\mathrm{r}=0.78$, respectively) with the average percent amylose of the 2 fields. Results from studies summarized by Stock (1999) demonstrated that sorghum hybrids with greater amylose content were less digestible than hybrids containing primarily amylopectin. If differences exist for digestibility among corn hybrids with lower amylose content, it would be expected that total VFA concentrations and OM digestibility would be negatively correlated to the percent amylose, not positively correlated.

Intakes observed for the heifers in Exp. 2 were lower as a percentage of body weight (1.9\%) compared with the finishing steers (2.3\%). The lower DM intakes may have slowed the rate of passage of feed particles from the rumen, thereby increasing the extent of degradation of hybrids that have harder kernel traits.

In both the feedlot performance study and metabolism study, wet corn gluten feed was included in all diets to mediate acidosis. If one hybrid had a very rapid degradation rate compared with the others, cattle performance may have been negatively impacted and animals consuming the hybrid with the greatest starch availability may have had the poorest performance (Owens et al., 1998). The inclusion of by-products, such as wet corn gluten feed, has been shown to reduce the incidence of subacute acidosis in feedlot cattle (Krehbiel et al., 1995).

Both the GMD and GSD were correlated $(P<0.05)$ to the Stenvert time to grind ( $\mathrm{r}=-0.81$, and 0.85 , respectively). As kernel hardness increased the GMD decreased, and the GSD increased. The distribution of particles for hybrid 3 was skewed toward a smaller particle size lowering the GMD on average, but not lowering the proportion of larger particles that were less digestible. Dry corn processed through a roller mill typically has a distribution from fine to coarse particles. It would be expected from the finer particle size that hybrid 3 would have similar or greater total tract nutrient digestibility based on results from Secrist et al. (1995) and Remond et al. (2004). In these studies, total tract starch digestibility increased as particle size decreased.

Though the current studies utilized dry-rolling as the processing method for the corn hybrids, results from this study may have been different if the hybrids were processed in a different manner. Macken et al. (2003) demonstrated that flinty and floury endosperm types of dent corn differed in digestibilities when fed as dryrolled corn, with the floury endosperm type performing $5.9 \%$ better than the flinty type. However, Macken et al. (2003) also showed that G:F was not different among the 2 endosperm types when fed as high-moisture corn. Results from Macken et al. (2003) indicate that hybrid differences may be dependent on processing method.

\section{IMPLICATIONS}

Cattle fed corn hybrids with heavier 1,000-grain weights and greater proportions of soft endosperm, indicated by the Stenvert hardness tests, gained more efficiently than cattle receiving corn hybrids with a lower 1,000-grain weight and a harder endosperm in a dry-rolled finishing diet. Corn 1,000-grain weight can be measured quickly and is potentially a simple method to determine relative differences among hybrids. The Stenvert tests are also rapid; however, special equipment is necessary. These kernel traits may provide a foundation of characteristics to use in selecting corn hybrids for cattle finishing rations.

\section{LITERATURE CITED}

AOAC. 1995. Official Methods of Analysis. 14th ed. Assoc. Off. Anal. Chem., Arlington, VA.

Behnke, K. C. 1994. Feed manufacturing technology IV. Am. Feed Industry Association, Inc., Arlington, VA.

Bergquist, R. R., and D. L. Thompson. 1992. Corn grain density characterized by two specific gravity techniques. Crop Sci. 32:1287-1290.

Brink, D. R., S. R. Lowry, R. A. Stock, and J. C. Parrott. 1990. Severity of liver abscesses and efficiency of feed utilization of feedlot cattle. J. Anim. Sci. 68:1201-1207.

Cooper, R. J., T. J. Klopfenstein, R. A. Stock, C. T. Milton, D. W. Herold, and J. C. Parrott. 1999. Effects of imposed feed intake variation on acidosis and performance of finishing steers. J. Anim. Sci. 77:1093-1099.

Cooper, R. J., C. T. Milton, T. J. Klopfenstein, T. L. Scott, C. B. Wilson, and R. A. Mass. 2002. Effect of corn processing on starch digestion and bacterial crude protein flow in finishing cattle. J. Anim. Sci. 80:797-804.

Erwin, E. S., D. J. Mareo, and E. M. Emery. 1961. Volatile fatty acid analysis of blood and rumen fluid by gas chromatography. J. Dairy Sci. 44:1768-1770.

Galyean, M. L. 1996. Protein levels in beef cattle finishing diets: industry application, university research, and systems results. J. Anim. Sci. 74:2860-2870.

Gramlich, S., M. Sindt, R. Stock, R. Britton, and W. Sahs. 1989. Corn hybrids for feedlot cattle. Neb. Beef Cattle Rep. MP 54:55-57.

Krehbiel, C. R., R. A. Stock, D. W. Herold, D. H. Shain, G. A. Ham, and J. E. Carulla. 1995. Feeding wet corn gluten feed to reduce subacute acidosis in cattle. J. Anim. Sci. 73:2931-2939.

Ladely, S. R., R. A. Stock, F. K. Goedeken, and R. P. Huffman. 1995. Effect of corn hybrid and grain processing method on rate of starch disappearance and performance of finishing cattle. J. Anim. Sci. 73:360-364.

Littell, R. C., P. R. Henry, and C. B. Ammerman. 1998. Statistical analysis of repeated measures data using the SAS procedures. J. Anim. Sci. 76:1216-1231.

Macken, C., G. Erickson, T. Milton, T. Klopfenstein, and H. Block. 2003. Effects of starch endosperm type and corn processing 
method on feedlot performance, nutrient digestibility and ruminal fermentation of high-grain diets. Neb. Beef Rep. MP 80A:32-34.

Mertens, D. R. 1987. Predicting intake and digestibility using mathematical models of rumen function. J. Anim. Sci. 65:1548-1558.

NRC. 1996. Nutrient Requirements of Beef Cattle. 7th ed. Natl. Acad. Press, Washington, DC.

Owens, F. N., D. S. Secrist, W. J. Hill, and D. R. Gill. 1997. The effect of grain source and grain processing on performance of feedlot cattle: A review. J. Anim. Sci. 75:868-879.

Owens, F. N., D. S. Secrist, W. J. Hill, and D. R. Gill. 1998. Acidosis in cattle: A review. J. Anim. Sci. 76:275-286.

Philippeau, C., F. Le Deschault, and B. Michalet-Doreau. 1999. Relationship between ruminal starch degradation and the physical characteristics of corn grain. J. Anim. Sci. 77:238-243.

Pomeranz, Y., Z. Czuchajowska, C. R. Martin, and F. S. Lai. 1985. Determination of maize hardness by the Stenvert Hardness Tester. Cereal Chem. 62:108-112.

Raun, N. S., and W. Burroughs. 1962. Suction strainer technique in obtaining rumen fluid samples from intact lambs. J. Anim. Sci. 21:454-457.

Reichert, R. D., R. T. Tyler, A. E. York, D. J. Schwab, J. E. Tatarynovich, and M. A. Mwasaru. 1986. Description of a production model of the tangential abrasive dehulling device and its application to breeder's samples. Cereal Chem. 63:201-207.

Remond, D., J. I. Caberera-Estrada, M. Champion, B. Chauveau, R. Coudure, and C. Poncet. 2004. Effect of corn particle size on site and extent of starch digestion in lactating dairy cows. J. Dairy Sci. 87:1389-1399.

Richards, C. J., J. F. Pederson, R. A. Britton, R. A. Stock, and C. R. Krehbiel. 1995. In vitro starch disappearance procedure modifications. Anim. Feed Sci. Tech. 55:35-45.

Secrist, D. S., W. J. Hill, F. N. Owens, and S. D. Welty. 1995. Effects of corn particle size on feedlot steer performance and carcass characteristics. Oklahoma Anim. Sci. Res. Rep. MP-943:99-104. Oklahoma State Univ., Stillwater.

Shandera, D. L., D. S. Jackson, and B. E. Johnson. 1997. Quality factors impacting processing of maize dent hybrids. Maydica 42:281-289.

Simon, J. 2001. Effects of particle size and mastication on starch digestion. M.S. Thesis, Univ. Nebraska, Lincoln.

Stock, R. A. 1999. Nutritional benefits of specialty grain hybrids in beef feedlot diets. J. Anim. Sci. 77(Suppl. 2):208-212.

Stock, R. A., M. H. Sindt, J. C. Parrott, and F. K. Goedeken. 1990. Effect of grain type, roughage level, and monensin level on finishing cattle performance. J. Anim. Sci. 68:3441-3445.

Williams, C. H., D. J. David, and O. Iismaa. 1962. The determination of chromic oxide in faeces by atomic absorption spectrophotometry. J. Agric. Sci. 59:381-385.

Zhu, T. 2002. Evaluation and development of several amylose determination methods. M.S. Thesis, Univ. Nebraska, Lincoln.

Zinn, R. A. 1990. Influence of steaming time on site of digestion of flaked corn in steers. J. Anim. Sci. 68:776-781. 